Ger J Exerc Sport Res 2021 · 51:468-473 https://doi.org/10.1007/s12662-021-00761-3 Received: 14 April 2021

Accepted: 15 September 2021

Published online: 13 October 2021

(c) The Author(s) 2021

\section{Introduction}

Within demographic change, generations are gradually becoming older on average. Whether the gained years of life can be spent independently and, above all, in a self-determined manner heavily depends on one component: health. The World Health Organization (WHO) defines health from a holistic point of view and explains with the concept of Healthy Aging a process of developing and stabilizing functionality for realizing individual well-being in old age (WHO, 2015). At the same time, however, the WHO construct indicates that there may be inequalities or unequal distributions for individuals within and between various determinants. For example, residents of resource-poor regions or settings are more likely to be affected by multimorbidity, especially those with a low socioeconomic status (Beard et al., 2016). Demographic changes are coupled with "cultural and social perceptions of the age structure" (Zrinščak \& Lawrence, 2014, p. 313) and also likely to result in an increase of various age-related diseases, which is why approaches to reduce (multi-)morbidity are becoming more and more important. The current state of scientific research points to numerous advantages of physical activity in old age and over the course of life, and in particular calls for avoiding a sedentary lifestyle. Internationally the epidemiological evidence for the positive correlation of physical activity in old age with the prevention and reduction of chronic diseases, the

Veronique Wolter (1D - Miriam Dohle - Lisa Sobo

TU Dortmund University, Department of Sport and Sport Science, Dortmund, Germany

\title{
Physical activities for older adults: Are local co-operations of sports clubs and care partners an option to increase access?
}

improvement of the functional and psychological status as well as the increase of well-being and social participation is evaluated as sufficient, in some cases even as strong (Bauman, Merom, Bull, Buchner, \& Fiatarone Singh, 2016). Overall, there has been emerging evidence in various disciplines that regular exercise maintain or improve well-being, self-efficacy and subjectively perceived everyday competence at an age when critical life events, such as the death of a partner or a change in the living situation, can usually lead to a reduction in successful coping strategies (Bauman et al., 2016; Chad et al., 2005; Chodzko-Zajko et al., 2009). Content for the design of health promotion programmes for older adults must therefore be framed by three central target dimensions: social participation, mental health and individual lifestyle. These goals can be achieved through multidisciplinary networks of actors in the living environment of the target group (Strümpel \& Billings, 2008).

In particular, it is worthwhile to take a look at the possibilities for people in need of care to access physical activity offerings. Expert standards for the mobility in care emphasize the important mediating role of care in the promotion of physical activity in the respective living environment-whether in inpatient or outpatient settings (DNQP, 2020). Of 


\begin{tabular}{|c|c|c|}
\hline Characteristics & Selection within the characteristics & $n$ \\
\hline \multirow[t]{2}{*}{ Age (in years) } & $50-64$ & 2 \\
\hline & 65 and older & 2 \\
\hline \multirow[t]{3}{*}{ Gender } & Female & 1 \\
\hline & Male & 3 \\
\hline & Diverse & 0 \\
\hline \multirow[t]{2}{*}{ Role in sports club ${ }^{\mathrm{a}}$} & Club management & 4 \\
\hline & Qualified trainer & 3 \\
\hline \multirow{4}{*}{$\begin{array}{l}\text { Regional allocation of } \\
\text { sports club }\end{array}$} & Rural: $<10,000$ inhabitants & 1 \\
\hline & (Small) town: $10,000-100,000$ inhabitants & 2 \\
\hline & City: $100,000-500,000$ inhabitants & 1 \\
\hline & Large city: $>500,000$ inhabitants & 0 \\
\hline \multirow{3}{*}{$\begin{array}{l}\text { Care partner within the } \\
\text { project }\end{array}$} & Stationary care & 2 \\
\hline & Day care & 1 \\
\hline & Outpatient care & 1 \\
\hline
\end{tabular}

ing health-promoting offerings for older adults in need of care, the different life situations and needs of the involved stakeholders should therefore be considered because they determine whether and how participation at a physical activity offer can take place (Wolter \& Hampel, 2020). Low-threshold access with focus on the individual, social and spatial/structural dimensions seems to be of particular importance for participation and involvement of older target groups and is defined by the fact that the offer does not exclude anyone in its framework conditions and does not require any specific skills in advance (Spicker \& Lang, 2011). Finally, social and spatial environments determine (perceived) barriers and therefore opportunities to strengthen individual resources and enable healthy ageing (Beard et al., 2016). Group based programmes guided by a qualified exercise trainer, in best practice assisted by a health care professional or care volunteer, give high motivation for less active older adults and convince with its provided social interaction to participate permanently (Balis, Strayer, Ramalingam, Wilson, \& Harden, 2019). All these aspects challenge social policy and social work programmes (Zrinščak \& Lawrence, 2014). A neighbourhood or living space gains particular strength through the establishment of networking structures that are as diverse as possible, address the needs of the residents and allow them to participate. A co- operation oflocal actors, e.g. educational, sports or outpatient rehabilitation facilities, social and nursing services as well as doctors, offers a very good opportunity to address different target groups across the life course and at the same time to bundle the resources and competences of those involved (BMFSFJ, 2016; Zrinščak \& Lawrence, 2014). Interestingly, local sports clubs are repeatedly mentioned as competent partners (BMG, 2009), in municipal practice-possibly due to very different basic structures to the system of care-they receive less attention.

Questions that arise at this stage: (1) Which aspects need to be looked at when starting and stabilizing a local cooperation of sports clubs and partners in care? and (2) What benefits and limits perceive sports clubs in these cooperations?

\section{Methods}

The project Moving Nursing Homes and Care Providers (2019-2022) is coordinated by the State Sports Federation of North Rhine-Westphalia, Germany. In this project local sports clubs cooperate with outpatient and inpatient care providers and start new sports programmes for older adults in need of care. Care partners differ locally and are not predefined. Examples are stationary care facilities, outpatient care services or day care. As part of the scientific evaluation, the main perspectives involved-local sports clubs, care providers and participants-are equally considered. To have a first inside view, for this paper four conducted qualitative interviews with representatives of sports clubs were analysed with the focus on the mentioned research questions. All interview partners ( $\bullet$ Table 1 ) were part of the club management for many years and had insight into organisational processes, but in three cases also were active exercise trainers for older adults. They were recruited via email announcements sent to all sports clubs participating in the project. Main topics of the semistructured interviews were the development of the co-operations to local partners in the care system, practical advises for municipal concepts, and (social) opportunities and barriers in the field of physical activities for older adults in need of care. In order to maintain the basic principle of openness and still provide the necessary structuring for the project specific research interest, the designed guideline was tested in advance with people close to the target group and adapted. The use of qualitative instruments opened a view on the individuality of experiences in context of the main project. With the purpose to identify opportunities and barriers for the local cooperations, the guided interviews were audio recorded and transcribed. Content analysis following Kuckartz (2018) was used. This method is suitable because of its appreciation of existing research and simultaneous openness to new knowledge while utilising a category system. Deductive categories were derived from existing literature about health promotion for older adults (in need of care), subcategories were developed inductively out of the interview material. The evaluation process involved several revisions by three team members. Because the project Moving Nursing Homes and Care Providers (2019-2022) and its scientific evaluation have not finished at this stage, the analysed interviews are first results, but there are still missing data to complete the comprehensive perspective of all involved stakeholders. 


\section{Results}

The evaluation of the interviews shows that the perceived opportunities and barriers of the sports clubs in organising and continuing a co-operation with local partners of outpatient and inpatient care are on the one hand clearly dependent on the local conditions, for example rural regions with a lower population density appreciate more direct communication paths through personal contacts than urban areas.

"These are the short distances in our village. We think about it briefly: Can we do it? What do we have to do? And then we start. In such a small village, of course, you know everyone. That's the advantage we have here." (f4)

On the other hand, the statements reflect structural and personal dimensions that are independent of location and cooperation, which are presented in the following (• Table 2).

\section{Local networks and co-operation to care partners}

In their daily work, sports clubs rarely have regular exchanges with care partners or representatives of the target group of older adults in need of care, for example outpatient and inpatient care institutions. However, they quickly find contact through existing networks or networks that are to be newly formed, which consist only of representatives of the organised sport or, in best case, already of actors from different professions. Besides the opportunity of information transfer, intensive networking can also support the further development of the club's range of offerings, and initiate new co-operations. In addition, these meetings include good opportunities to exchange ideas on bureaucratic hurdles and organisational steps. A full-time or experienced volunteer representative from the sports federations or the municipality can provide additional advice, especially for sports clubs with little experience in networking.

The workload of getting connected with a local care partner for the first time is often described as an inhibiting factor. Sports clubs sometimes have to convince the management of the care partners (e.g. stationary care facilities) and also provide organisational support, before they start with the implementation. However, for both partners from sport and care, a great added value is the external presentation and expansion of services. New contacts and possibly further co-operation opportunities arise through recommendation.

Often the long-term financing of a physical activity programme is the biggest problem and causes well-intentioned short-term projects to fail quickly. The bureaucratic steps for alternative financing options, besides a sports club membership, were sometimes perceived as very laborious and time-consuming by the interviewees. At the same time, the financial resources of the participants are often very limited. Co-operation partners that make clear agreements on personal responsibilities and (financial) organisation of the joint project right at the beginning and meet as equals by recognizing each other's competences seem to support sustainability.

\section{Qualification and competences of trainers}

On a personal level the interviewees reported the ambivalence in continuing the sporting programmes. Qualified and often volunteer trainers are happy to see the gratitude and motivation of most of the participants, who seem to get improved everyday structure and increased social contacts. But the psychological burden and challenges connected to the participants' physical and cognitive conditions are a limiting factor for the exercise trainers. In addition, offering sports for older adults in need of care requires a lot of flexibility and sensitivity. A good qualification and teaching experience are recommended. In one case the solution was adopted into the regular club structure in the long term: initiating discussion rounds, supported by a supervisor, seems to decrease the psychological strain on the exercise trainers.

\section{Social responsibility}

The sports clubs feel it is their social responsibility to create health-promoting
Ger J Exerc Sport Res 2021 · 51:468-473 https://doi.org/10.1007/s12662-021-00761-3 (c) The Author(s) 2021

\section{Wolter $\cdot$ M. Dohle $\cdot$ L. Sobo \\ Physical activities for older adults: Are local co- operations of sports clubs and care partners an option to increase access?}

\section{Abstract}

Group-based physical activity brings high and long-term added value for the participants. Especially for older adults in need of care, this development is dependent on interdisciplinary thinking and the networking of local structures. Studies underline the consideration of the communication and access options that are needed to be able to promote the target group's health through exercise programmes. Sports clubs are repeatedly mentioned as competent partners in health promotion, but in municipal practice-possibly due to very different basic structures to the system of care-they receive less attention. The project Moving Nursing Homes and Care Providers (2019-2022) is coordinated by the State Sports Federation of North RhineWestphalia, Germany. Local sports clubs cooperate with providers of outpatient and inpatient care to start new sports programs for older adults in need of care. As part of the scientific evaluation, the perspectives involved are equally considered and their motives and needs are analysed. For this paper, four conducted qualitative interviews with representatives of sports clubs were analysed with the focus on opportunities and barriers for local partnerships between sports clubs and care. Results show structural and personal parameters that have to be looked at from the beginning Local networks are essential for sports clubs to get in contact with potential partners and to reflect initiated processes. Although aspects of (financial) organisation is an often named topic, sports clubs have the opinion that they have the social responsibility to influence developments in their neighbourhood for all generations positively.

\section{Keywords}

Demographic change $\cdot$ Participation $\cdot$ Healthpromoting setting - Equal access to physical activity · Resource-orientated activity 


\begin{tabular}{|c|c|c|}
\hline Categories & Subcategories & Representative quote \\
\hline \multirow{3}{*}{$\begin{array}{l}\text { Local networks } \\
\text { and } \\
\text { co-operation to } \\
\text { care partners }\end{array}$} & $\begin{array}{l}\text { Access to target group, } \\
\text { information and potential } \\
\text { partners }\end{array}$ & $\begin{array}{l}\text { "We now have a new senior citizens' representative in the city, with whom I am in lively discussion and } \\
\text { we exchange ideas. What is possible? What good things can be initiated for older adults? What can be } \\
\text { initiated, also through other networks?" (f3) }\end{array}$ \\
\hline & $\begin{array}{l}\text { External presentation } \\
\text { and expansion of service }\end{array}$ & $\begin{array}{l}\text { "They [the care partner] are really eager for the whole thing to run because they need it as advertising } \\
\text { in order to be able to stand up against the big ones, like Caritas [...]. You have to have a unique selling } \\
\text { point." (f4) }\end{array}$ \\
\hline & $\begin{array}{l}\text { Initiation } \\
\text { and sustainability of co- } \\
\text { operation }\end{array}$ & $\begin{array}{l}\text { "My advice would be to really regulate this contractually in a sensible way, so that everyone knows what } \\
\text { to expect and no one can talk their way out of it and say, 'No, but we discussed that differently'. Because } \\
\text { then there is trouble." (f4) }\end{array}$ \\
\hline \multirow[t]{2}{*}{$\begin{array}{l}\text { Qualification } \\
\text { and compe- } \\
\text { tences }\end{array}$} & Personal competences & $\begin{array}{l}\text { "But you also have to make sure that you set limits because you can't help everyone. [...] What I personally } \\
\text { find exciting about this clientele is the challenge. That is why, in my opinion, you have to have experi- } \\
\text { ence." (m2) }\end{array}$ \\
\hline & Teaching experience & $\begin{array}{l}\text { "Many trainers can only teach what they have prepared at home. But with these groups, you can't just } \\
\text { come and go. You also have to be flexible, very flexible, and maybe say: OK, today we're not going to do } \\
\text { what I had planned, but we have to talk first because of an incident." (m2) }\end{array}$ \\
\hline \multirow[t]{2}{*}{$\begin{array}{l}\text { Social responsi- } \\
\text { bility }\end{array}$} & $\begin{array}{l}\text { Shared responsibility } \\
\text { in the neighbourhood }\end{array}$ & $\begin{array}{l}\text { "The next generation }[\ldots . .] \text { has to make sure that older adults in need of care are moved somehow. It is not } \\
\text { only care that have this task, but also sport." }(\mathrm{m} 2)\end{array}$ \\
\hline & Social outcome & $\begin{array}{l}\text { "It's just great to work with people like that. They are incredibly grateful when you come. They join in, } \\
\text { they follow the lesson closely, they try things out, they are highly motivated. And they are happy, they } \\
\text { have fun with each other, this togetherness, telling a joke and so on. It is simply a clientele where you can } \\
\text { achieve a lot." (f1) }\end{array}$ \\
\hline
\end{tabular}

options for older adults in their neighbourhood and to positively support their well-being. Experience shows that group sporting activities can lead to increased social interaction and that the joint exercise highly motivates older adults in need of care.

\section{Discussion}

A particular challenge for future health promotion and prevention programmes for older and very old adults will be to overcome inequalities based on socioeconomic/demographic characteristics. Political structures and their decisions occupy a key role in supporting the goal of people being able to live self-determined and independent lives for as long as possible in old age. Above all, the view of otherwise invisible older adults in society can be sharpened through politically accompanied or initiated actions at the meso and macro levels (Altgeld, 2009; BAGSO, 2020; BMFSFJ, 2016; Strümpel \& Billings, 2008). This is about raising awareness for older adults who are disadvantaged by or in their life situation and accordingly cannot participate in social life (Baumgartner, Kolland, \& Wanka, 2013). Our study shows that sports groups give a good opportunity to increase social and general health activity for older people in need of care, but this target group needs qualified and experienced trainers. Group settings seem to be highly motivating and support positive emotions within the target group.

Despite the known challenges, studies underline the need to follow the WHO statements on healthy ageing and to consider supportive approaches in the different living spaces of older adults to promote physical functioning and other dimensions that are indispensable for independence (Sherrington et al., 2019). Our findings support that sports clubs are well distributed in rural and urban regions. For community-dwelling older adults, they can fill an important offer gap if clubs receive support from the also good networks of care and access the target group better together. At this point the project Moving Nursing Homes and Care Providers plays an important role by bringing together experienced institutions and organisations with different competences, and also focussing on various living situations (stationary care, day care, outpatient care settings).

In the selection of communication paths, particular attention should be paid to sensitivity to different socioeconomic disparities within the target group in order not to intensify the perpetuation of health inequalities in old age (Baker, Francis, Soares, Weightman, \& Foster, 2015). The recommendations indicate the consideration and reflection of diversity and social inequality in old age and emphasize low-threshold access for the older population, which can only be established by consistently promoting and enabling structural networking at all levels (BMFSFJ, 2016). On the ground, municipal coordination bodies can become relevant for establishing and maintaining health promotion measures by creating access points for older adults and especially for vulnerable target groups together with already active actors, e.g. sports clubs (BAGSO, 2020). A public health approach, also mentioned by the WHO, is about creating sustainable enabling structures to shape individual choices and therefore achieve health goals (Beard et al., 2016; Chad et al., 2005). The results of this paper underline the existing literature. Co-operations of sports clubs and care partners have a good chance to provide access to more physical activity within the group of older adults in need of care. However, certain parameters (working as equal partners, consider needs of heterogeneous target group, organising a sustainable concept etc.) must be given in advance and during implementation, and must be repeatedly 
reminded in order to be able to design the physical activity offerings in a target group-oriented and sustainable way. The initiation and long-term maintenance of the partnerships should be further evaluated in the future.

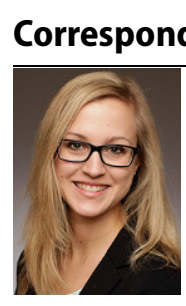

\section{Dr. Veronique Wolter}

TU Dortmund University,

Department of Sport and

Sport Science

Otto-Hahn-Str. 3,

44227 Dortmund, Germany

veronique.wolter@tu-

dortmund.de

Funding. The author disclosed receipt of the following financial support for the research, authorship, and/or publication of this article: The project 'Moving Nursing Homes and Care Providers' (2019-2022) is funded by the Ministry for Work, Health and Social Affairs of the State of North Rhine-Westphalia and the State Associations of Long-Term Care Insurance (Germany).

Funding. Open Access funding enabled and organized by Projekt DEAL.

\section{Declarations}

Conflict of interest. V. Wolter, M. Dohle and L. Sobo declare that they have no competing interests.

For this article no studies with human participants or animals were performed by any of the authors. All studies performed were in accordance with the ethical standards indicated in each case.

Open Access. This article is licensed under a Creative Commons Attribution 4.0 International License, which permits use, sharing, adaptation, distribution and reproduction in any medium or format, as long as you give appropriate credit to the original author(s) and the source, provide a link to the Creative Commons licence, and indicate if changes were made. The images or other third party material in this article are included in the article's Creative Commons licence, unless indicated otherwise in a credit line to the material. If material is not included in the article's Creative Commons licence and your intended use is not permitted by statutory regulation or exceeds the permitted use, you will need to obtain permission directly from the copyright holder. To view a copy of this licence, visit http://creativecommons.org/licenses/by/4.0/.

\section{References}

Altgeld, T. (2009). Gemeindenahe Gesundheitsförderung für ältere Menschen [Communitybased health promotion for older people. Prävention und Gesundheitsförderung, 4(3), 149-157. https://doi.org/10.1007/s11553-0090185-x
BAGSO - Bundesarbeitsgemeinschaft der Seniorenorganisationen e.V. (2020). Positionspapier. Jetzt erst recht! Lebensbedingungen älterer Menschen verbessern [Position paper. Now more than ever! Improving the living conditions of older people. https://www.bagso.de/fileadmin/user upload/bagso/06_Veroeffentlichungen/2020/ BAGSO-Positionspapier_Jetzt_erst_recht_ Lebensbedingungen_aelterer_Menschen_ verbessern.pdf. Accessed 14 Apr 2021.

Baker, P.R. A., Francis, D. P., Soares, J., Weightman, A. L., \& Foster, C. (2015). Community wide interventions for increasing physical activity. The Cochrane Database of Systematic Reviews. https://doi.org/10.1002/14651858.CD008366. pub3.

Balis, L.E., Strayer, T., Ramalingam, N., Wilson, M., \& Harden, S. M. (2019). Open-access physical activity programs for older adults: a pragmatic and systematic review. The Gerontologist, 59(4) e268-e278. https://doi.org/10.1093/geront/ gnx195.

Bauman, A., Merom, D., Bull, F.C., Buchner, D.M., \& Fiatarone Singh, M.A. (2016). Updating the evidence for physical activity: Summative reviews of the epidemiological evidence, prevalence, and interventions to promote 'active aging. The Gerontologist, 56(Suppl2), S268-S280. https://doi.org/10.1093/geront/ gnw031

Baumgartner, K., Kolland, F., \& Wanka, A. (2013). Altern im ländlichen Raum. Entwicklungsmöglichkeiten und Teilhabepotenziale [Ageing in rural areas. Development opportunities and participation potentials. Stuttgart: Kohlhammer.

Beard, J. R., Officer, A., de Carvalho, I. A., Sadana, R., Pot, A. M., Michel, J.-P., Lloyd-Sherlock, P., EppingJordan, J. E., Peeters, G. M. E. E., Mahanani, W. R. Thiyagarajan, J. A., \& Chatterji, S. (2016). The world report on ageing and health: a policy framework for healthy ageing. The Lancet, 387(10033), 2145-2154. https://doi.org/10. 1016/S0140-6736(15)00516-4

BMFSFJ - Bundesministerium für Familie, Senioren, Frauen und Jugend (2016). Siebter Altenbericht: Sorge und Mitverantwortung in der Kommune - Aufbau und Sicherung zukunftsfähiger Gemeinschaften und Stellungnahme der Bundesregierung [Seventh Report on Ageing: Care and co-responsibility in the community-building and securing sustainable communities and statement by the Federal Government]. https://www.bmfsfj.de/blob/120144/ 2a5de459ec4984cb2f83739785c908d6/7altenbericht---bundestagsdrucksache-data. pdf

BMG - Bundesministerium für Gesundheit (2009). Gesundheitsförderung und Prävention für ältere Menschen im Setting Kommune [Health promotion and prevention for older people in the community setting]. https://www. in-form.de/fileadmin/Dokumente/Materialien/ Gesundheitsf\%C3\%B6rderung_und_Pr\%C3 \%A4vention.pdf. Accessed 14 Apr 2021.

BMG - Bundesministerium für Gesundheit (2017). Glossar. Begriff Pflegebedürftigkeit [Glossary. Term need of care]. https://www. bundesgesundheitsministerium.de/service/ begriffe-von-a-z/p/pflegebeduerftigkeit.html. Accessed 14 Apr 2021.

Chad, K. E., Reeder, B. A., Harrison, E. L., Ashworth, N. L., Sheppard, S. M., Schultz, S. L., Bruner, B. G. Fisher, K. L., \& Lawson, J.A. (2005). Profile of physical activity levels in community-dwelling older adults. Medicine and Science in Sports and Exercise, 37(10), 1774-1784. https://doi.org/10. 1249/01.mss.0000181303.51937.9c

Chodzko-Zajko, W. J., Proctor, D. N., Fiatarone Singh, M. A., Minson, C. T., Nigg, C. R., Salem, G. J., \& Skinner, J. S. (2009). American College of Sports Medicine position stand: Exercise and physical activity for older adults. Medicine and Science in Sports and Exercise, 41(7), 1510-1530. https:// doi.org/10.1249/MSS.0b013e3181a0c95c

Dechamps, A., Diolez, P., Thiaudi, E., Tulon, A., Onifade, C., Vuong, T., Helmer, C., \& Bourdel-Marchasson, I. (2010). Effects of exercise programs to prevent decline in health-related quality of life in highly deconditioned institutionalized elderly persons. A randomized controlled trial. Arch Intern Med, 170(2), 162-169. https://doi.org/10.1001/ archinternmed.2009.489

Destatis - Statistisches Bundesamt (2018). Pflegestatistik. Pflege im Rahmen der Pflegeversicherung. Deutschlandergebnisse [Care statistics. Long-term care within the framework of long-term care insurance. German results]. https://www.destatis.de/DE/Themen/ Gesellschaft-Umwelt/Gesundheit/Pflege/ Publikationen/Downloads-Pflege/pflegedeutschlandergebnisse-5224001179004. pdf?_blob=publicationFile. Accessed $14 \mathrm{Apr}$ 2021.

DNQP - Deutsches Netzwerk für Qualitätsentwicklung in der Pflege (2020). Konsultationsfassung zum Expertenstandardsnach§113aSGBXI,Erhaltung und Förderung der Mobilität in der Pflege' (Aktualisierung 2020) [Consultation version of the expert standard according to §113a SGB XI 'Maintenance and Promotion of mobility in care] https://www.gs-qsa-pflege.de/wp-content/ uploads/2020/12/Expertenstandard-\%E2\%80 \%9EErhaltung-und-Fo\%CC\%88rderung-derMobilita\%CC\%88t-in-der-Pflege\%E2\%80\%9CAktualisierung-2020.pdf. Accessed 14 Apr 2021.

Hoppe, T. (2018). Soziale Rahmenbedingungen körperlich sportiver Aktivitäten im Pflegeheim: Ergebnisse einer qualitativen explorativen Studie [Social framework conditions of physical sport activities in nursing homes: results of a qualitative explorative study. Pflege \& Gesellschaft, 23(3), 262-278.

Jacobs, K., Kuhlmey, A., Greß, S., Klauber, J., \& Schwinger, A. (2020). Pflege-Report 2019 [Care Report 2019]. Wiesbaden: Springer.

Kuckartz, U. (2018). Qualitative Inhaltsanalyse. Methoden, Praxis, Computerunterstützung [Qualitative content analysis. Methods, practice, computer support]. Weinheim: Beltz Juventa.

Nowossadeck, S. (2018). Pflegebedürftige in Deutschland [People in need of care in Germany]. In C. Tesch-Römer \& C. Hagen (Eds.), DZA Fact Sheet: Ausgewählte Aspekte zur informellen häuslichen Pflege. https://www.dza.de/fileadmin/dza/pdf/ factsheets/FactSheet_Inform_haeusl_Pflege. pdf.

Sherrington, C., Fairhall, N.J., Wallbank, G.K., Tiedemann, A., Michaleff, Z. A., Howard, K., Clemson, L., Hopewell, S., \& Lamb, S. E. (2019). Exercise for preventing falls in older people living in the community. The Cochrane Database of Systematic Reviews. https://doi.org/10.1002/ 14651858.CD012424.pub2.

Spicker, I., \& Lang, G. (2011). Kommunale Gesundheitsförderung mit Fokus auf ältere Menschen [Community health promotion with a focus on older people]. https://fgoe.org/sites/fgoe.org/ 
files/2017-10/2011-11-02.pdf. Accessed 14 Apr 2021.

Strümpel, C., \& Billings, J. (2008). Health pro elderly: overview on health promotion for older people. European Report. https://www.kent. ac.uk/chss/docs/hpe_European_Report_draft_ May9_2008_finaldraft.pdf. Accessed 14 Apr 2021.

Trevisan, C., Rizzuto, D., Maggi, S., Sergi, G., Wang, H.X., Fratiglioni, L., \& Welmer, A.-K. (2019). Impact of social network on the risk and consequences of injurious falls in older adults. Journal of the American Geriatrics Society, 67(9), 1851-1858. https://doi.org/10.1111/jgs.16018

WHO - World Health Organization (2015). World report on ageing and health. https://apps.who.int/iris/bitstream/handle/ 10665/186463/9789240694811_eng.pdf; jsessionid=7F1CFBBED0FC2FAF1A6EA3EB96 F9CB6F? sequence=1. Accessed 14 Apr 2021.

Wolter, V., \& Hampel, S. (2020). "It wasn't like we expected": analyzing (non-)participation of family Caregivers of people with dementia in sports activities from different perspectives. Journal of Applied Gerontology. https://doi.org/ 10.1177/0733464820917291.

Zrinščak, S., \& Lawrence, S. (2014). Active ageing and demographic change: challenges for social work and social policy. European Journal of Social Work, 17(3), 313-321. https://doi.org/10.1080/ 13691457.2014.919088. 